\title{
ORIGINAL ARTICLEIARTIGO ORIGINAL
}

\section{Evaluation study of the garbage codes research project in the Northern region of Brazil}

\author{
Estudo avaliativo do projeto de investigação de óbitos por códigos garbage na \\ região Norte do Brasil

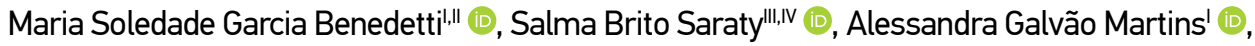 \\ Marina Jorge de Mirandav (D), Daisy Maria Xavier de Abreuvi (iD)
}

\begin{abstract}
Introduction: The term "garbage code" (GC) is used to designate an underlying cause of death that is not very useful for the health policy, since it does not adequately identify actions to prevent and control diseases and health problems. Objective: To evaluate the results of GC investigation on changing causes of death in 17 municipalities in the Brazilian Northern region in 2017. Methods: This is a cross-sectional study on the results of the investigation of deaths with GC in selected hospitals in 17 cities in the seven states of the Northern region, as part of the Data for Health Initiative of the Ministry of Health (MH). In these hospitals, the underlying causes of deaths occurring in 2017 were reviewed, and the GC investigation protocol was applied to deaths with GC. Results: In 2017, 37,082 deaths occurred in the 17 municipalities studied, of which $29.3 \%(n=10,878)$ were GC and $83.2 \%$ were priority GC. Among the priority GCs, $25.9 \%$ were investigated, of which $79.1 \%$ had a change in the underlying cause. Discussion: There is great variation among the 17 municipalities in relation to the proportion of GC. In 13 of the municipalities studied, the underlying cause of death was reclassified in at least $70 \%$ of the cases investigated for the priority GC. Conclusion: Despite the improvement in reducing the proportion of underlying causes of death with GC in this study, there is still a need for greater investment in training professionals and increasing services to carry out death investigations, in order to ensure the sustainability of the project in the region.
\end{abstract}

Keywords: Brazil. Cause of death. Health assessment.

Health Department of Roraima - Boa Vista (RR), Brazil.

"Federal University of Roraima - Boa Vista (RR), Brazil.

"'Fundação Santa Casa de Misericórdia do Pará - Belém (PA), Brazil.

"State University of Pará - Belém (PA), Brazil.

'Department of Analysis on Health and Surveillance of Non transmissible Diseases, Secretariat of Health Surveillance, Ministry of Health - Brasília (DF), Brazil.

"Center for Collective Health Education, School of Medicine, Universidade Federal de Minas Gerais - Belo Horizonte (MG), Brazil. Corresponding author: Daisy Maria Xavier de Abreu. Avenida Alfredo Balena, 190, Santa Efigênia, CEP: 30130-1000, Belo Horizonte, MG, Brazil. Email: dmxa@medicina.ufmg.br

Conflict of interests: nothing to declare - Financial support: Funding from Vital Strategies as part of the Bloomberg Philanthropies Data for Health Initiative (Project 23998 Fundep/UFMG). 
RESUMO: Introdução: O termo "código garbage" (CG) é usado para designar uma causa básica de óbito pouco útil para o setor de saúde, uma vez que não permite identificar adequadamente ações para prevenção e controle das doenças e agravos de saúde. Objetivo: avaliar os resultados da investigação de óbitos por CG em 17 municípios da região Norte no ano de 2017. Métodos: Estudo transversal sobre a investigação dos óbitos por CG em hospitais públicos de 17 municípios dos 7 estados da região Norte, como parte do projeto Dados para a Saúde do Ministério da Saúde (MS). Nesses hospitais foram revisadas as causas básicas de morte dos óbitos ocorridos em 2017 e aplicado o protocolo de investigação de CG do MS. Resultados: Em 2017, ocorreram 37.082 óbitos nos 17 municípios que participaram do estudo, destes, 29,3\% (n=10.878) eram CG total e, destes, 83,2\% eram CG prioritários. Dentre os CG prioritários, 25,9\% foram investigados e, destes, $79,1 \%$ mudaram a causa básica. Discussão: Observou-se uma grande variação entre os 17 municípios em relação à proporção de CG. Chama atenção que 13 municípios estudados reclassificaram a causa básica de morte em pelo menos $70 \%$ dos casos investigados para os CG prioritários. Conclusão: Apesar da melhoria ocorrida com redução na proporção de CG como causa básica de morte nos municípios analisados, ainda se faz necessário maior investimento em capacitação de profissionais e ampliação dos serviços que investigam os óbitos, de modo a permitir a sustentabilidade do projeto na região.

Palavras-chave: Brasil. Causa básica de morte. Avaliação em saúde.

\section{INTRODUCTION}

Knowing the mortality profile of a population is essential for health managers, as it allows them, in addition to recognizing the main diseases among population groups, the planning of health actions and public policies aimed at improving community health conditions ${ }^{1}$.

The Mortality Information System (MIS), created in 1975, is a tool of the Ministry of Health $(\mathrm{MoH})$ to store and monitor the data on deaths in the country, which is very useful for health surveillance in regions, states and municipalities for allowing them to analyze the mortality profile in a given period and place $^{2}$. However, for such a tool to contribute positively to the analysis of the death causes of a population group, the information generated by the death certificate (DC) records and investigation forms must have the quality criteria standardized by the $\mathrm{MoH}^{3}$.

In recent years, investments have been made feasible in Brazil, if considering to improve the quality of mortality information ${ }^{3}$. However, studies on mortality indicate that the quality of information on deaths is still a great challenge, due to the inequalities in coverage and quality of information on causes of death ${ }^{4}$. Recently studies to assess the quality of information on the underlying cause of death also analyze - in addition to the ill-defined causes present in ICD-10 chapter XVIII - other ill-defined causes and incomplete diagnoses, defined as garbage codes.

The term garbage code or garbage cause (GC) has been applied in studies on Global Burden of Disease (GBD), which assess that some codes of the International Statistical Classification of Diseases and Related Health Problems - 10th Revision (ICD-10) should 
not be considered as an underlying cause because they are not useful for the health sector, since they do not allow proper identification of actions for prevention and control of diseases and health problems $s^{5}$. A high proportion of GC affects the quality of information on causes of death, making it difficult to identify priorities and plan actions ${ }^{6}$.

The reduction in the percentage of deaths by GC is one of the main initiatives of the Department of Analysis on Health and Surveillance of Non transmissible Diseases (Departamento de Análise em Saúde e Vigilância de Doenças e Agravos Não-transmissíveis DASNT) of the Secretariat of Health Surveillance (SHS) of MoH. Therefore, a pilot project was developed to improve the diagnosis of cause of death in Brazil in 7 cities of the Brazilian regions. During its development, a large number of GC in DC emitted in hospitals was found. Moreover, in most cases, the research has been able to correcting the underlying cause of death from a GC to another more useful cause for public health analysis ${ }^{7}$. From these results, the research proposal was expanded to 60 municipalities, from the 5 regions of the country, and the project was named "Dados para a Saude - D4H (Data for Health Initiative - Brazil): investigação de códigos garbage - estudo avaliativo.” The project aims to reclassify the underlying cause of death of the investigated cases ${ }^{8}$. The research effort of GC is an important strategy to motivate the improvement of the information quality ${ }^{9}$, considering that it identifies to the health services the main problems related to filling in the causes of death in DC.

The North is one of the Brazilian regions that historically had a high percentage of deaths from GC. However, it was one of the regions where the proportion of these deaths significantly decreased, as a result of the specific investment made by the Ministry of Health for the improvement of mortality information. This investment ranged from data collection regulation, flow and periodicity of death reporting, to dissemination of data and technical publications and training of human resources, especially of underlying cause coders, among other measures ${ }^{10}$. However, the number of studies on data quality in the region is small, even though information systems present greater difficulties when compared to the South and Southeast regions.

In this context, this study aims to evaluate the results of GC investigation in 17 municipalities in the Northern region in 2017.

\section{METHODS}

This is a cross-sectional, descriptive study, based on data of deaths by GC in the municipalities that participated in the Health Data project of northern states in 2017.

The northern region, made up of 7 states-Acre (AC), Amapá (AP), Amazonas (AM), Pará (PA), Rondonia (RO), Roraima (RR) and Tocantins (TO)-is known to be the largest in territorial extension, occupying an area of more than 3.8 million $\mathrm{km}^{2}$, which corresponds to $45.2 \%$ of the national territory ${ }^{11}$, and having the lowest population density of 4.7 inhabitants per $\mathrm{km}^{2}$, with a population of approximately 18 million inhabitants in 2017 , about $8 \%$ 
of the Brazilian population ${ }^{12}$. This region has an extensive area of indigenous reserve and riverside population, with great difficulty in access to transportation and health services.

The Data for Health project was implemented in the 7 states of the northern region, in public hospitals in 17 municipalities (Figure 1). In these hospitals, the underlying causes of death (original cause) among residents in 2017 were reviewed and identified deaths from GC were investigated using the GC investigation protocol of $\mathrm{MoH}^{8}$. The investigation steps are standardized and were performed by trained staff including a certifying physician, who uses strategies such as reviewing the underlying causes of death in the patient's medical records, examination results in sectors such as central public health laboratories, emergency care units, among others.

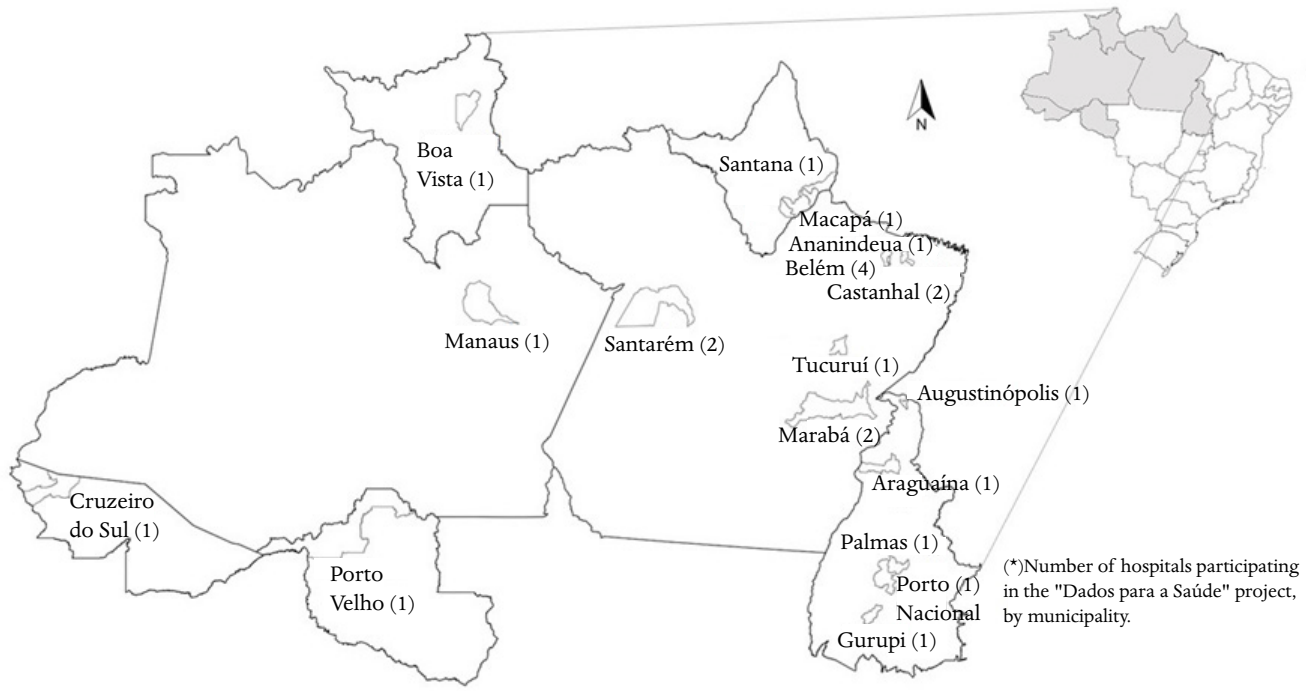

Figure 1. Municipalities and hospitals participating in the "Dados para a Saúde-D4H (Data for Health Initiative - Brazil): investigação de códigos garbage - estudo avaliativo." North Region, Brazil.

The instrument used for the research was the hospital ill-defined cause death investigation form (IOCMD-H). This form is intended to standardize the investigation of deaths classified as GC of hospital occurrence. The data from the form were used to feed the DASNT Collect system (version 2.2.6), created to storage this data.

The MIS database for 2017 was used in this study. The total and priority GC were surveyed by federative unit and municipality of residence. Based on GBD 2015, the following priority GC were considered: ill-defined causes (R00-R99, except R95), stroke (CVA) unspecified as hemorrhagic or ischemic (I64, I67.4, I67.9, I69.4, I69.8), septicemia (A40-A41), heart failure and unspecified heart disease (I50, I51), essential hypertension (I10), unspecified neoplasia (C26, C55, C76, C78, C79, C80), pulmonary embolism (I26), pneumonia (J15.9, $\mathrm{J} 18)$, respiratory failure and other respiratory disorders (J96, J98), renal failure (N17, N19), external causes of undetermined intent and unspecified accidents (US) (Y10-Y34, X59), US traffic accidents and US homicides $(\text { V89, Y09 })^{13}$. 
Data were tabulated using the Excel ${ }^{\circledR}$ program and the following indicators were calculated: (1) percentage of GC in relation to the total number of deaths; (2) percentage of GC that was investigated in relation to the total deaths from these causes; (3) percentage of GC that changed the underlying cause after investigation in relation to the total deaths from these causes; (4) percentage of priority GC, in relation to the total GC; (5) percentage of priority GC investigated; (6) percentage of priority GC that changed cause after the investigation, in relation to the total priority GC; (7) variation of change in underlying cause group of priority GC after investigation.

This study was approved by the Ethics and Research Committee of the Universidade Federal de Minas Gerais (CAEE 75555317.0.0000.5149) and developed according to the ethical precepts established in Ordinance No. 466/2012 of the National Health Council.

\section{RESULTS}

There were 37,082 deaths in the 17 municipalities participating in the study in 2017, which represented $44.7 \%$ of the approximately 83,000 deaths that occurred in the Northern region in 2017. In these municipalities, 11,004 were GC, representing $29.7 \%$. The proportion of GC ranged from $18.5 \%$ in Palmas (TO) to $40 \%$ in Santarém (PA). Priority GC corresponded to $82.2 \%(n=9,051)$, with proportions ranging from $79 \%$ in Araguaína (TO) to $89 \%$ in Marabá (PA) (Table 1).

Table 1. Number of deaths classified as total and priority GC by municipality of residence. North Region, 2017.

\begin{tabular}{|c|c|c|c|c|c|c|}
\hline \multirow{2}{*}{ State } & \multirow{2}{*}{$\begin{array}{l}\text { Municipality of } \\
\text { residence }\end{array}$} & \multirow{2}{*}{ No. of deaths } & \multicolumn{2}{|c|}{ Total GC } & \multicolumn{2}{|c|}{ Priority GC } \\
\hline & & & No. & $\%$ & No. & $\%^{1}$ \\
\hline Acre & Cruzeiro do Sul & 426 & 105 & 24.6 & 93 & 88.6 \\
\hline Amapá & Macapá & 2,120 & 674 & 31.8 & 587 & 87.1 \\
\hline Amazonas & Manaus & 10,631 & 3,341 & 31.4 & 2,840 & 85.0 \\
\hline \multirow[t]{7}{*}{ Pará } & Ananindeua & 2,748 & 775 & 28.2 & 626 & 80.8 \\
\hline & Belém & 9,309 & 2,464 & 26.5 & 1,932 & 78.4 \\
\hline & Castanhal & 1,047 & 336 & 32.1 & 287 & 85.4 \\
\hline & Marabá & 1,405 & 496 & 35.3 & 447 & 90.1 \\
\hline & Santarém & 1,663 & 658 & 39.6 & 547 & 83.1 \\
\hline & Tucuruí & 481 & 107 & 22.2 & 93 & 86.9 \\
\hline & Santana & 477 & 134 & 28.1 & 121 & 90.3 \\
\hline Rondônia & Porto Velho & 2,296 & 669 & 29.1 & 585 & 87.4 \\
\hline
\end{tabular}


Table 1. Continuation.

\begin{tabular}{|l|c|c|c|c|c|c|}
\multirow{2}{*}{ State } & \multirow{2}{*}{$\begin{array}{c}\text { Municipality of } \\
\text { residence }\end{array}$} & \multirow{2}{*}{ No. of deaths } & \multicolumn{2}{|c|}{ Total GC } & \multicolumn{2}{|c}{ Priority GC } \\
\cline { 4 - 7 } & & & No. & $\%$ & No. & $\%{ }^{1}$ \\
\hline \multirow{2}{*}{ Roraima } & Boa Vista & 1,545 & 417 & 27.0 & 320 & 76.7 \\
\hline \multirow{2}{*}{ Tocantins } & Araguaína & 1,011 & 266 & 26.3 & 215 & 80.8 \\
\cline { 2 - 7 } & Augustinópolis & 107 & 33 & 30.8 & 28 & 84.8 \\
\cline { 2 - 7 } & Gurupi & 512 & 125 & 24.4 & 97 & 77.6 \\
\cline { 2 - 7 } & National Harbor & 318 & 91 & 28.6 & 78 & 85.7 \\
\cline { 2 - 7 } & Palmas & 986 & 187 & 19.0 & 155 & 82.9 \\
\hline \multirow{2}{*}{ Total } & & 37,082 & 10,878 & 29.3 & 9,051 & 83.2 \\
\hline
\end{tabular}

' Regarding the number of priority GC.

Source: Mortality Information System.

Of the total GC, $26.3 \%$ ( $\mathrm{n}=2,895)$ were investigated, and the proportion of deaths investigated ranged from $7 \%(n=245)$ in Manaus $(A M)$ to $96.4 \%(n=107)$ in Cruzeiro do Sul (AC) (Figure 2).

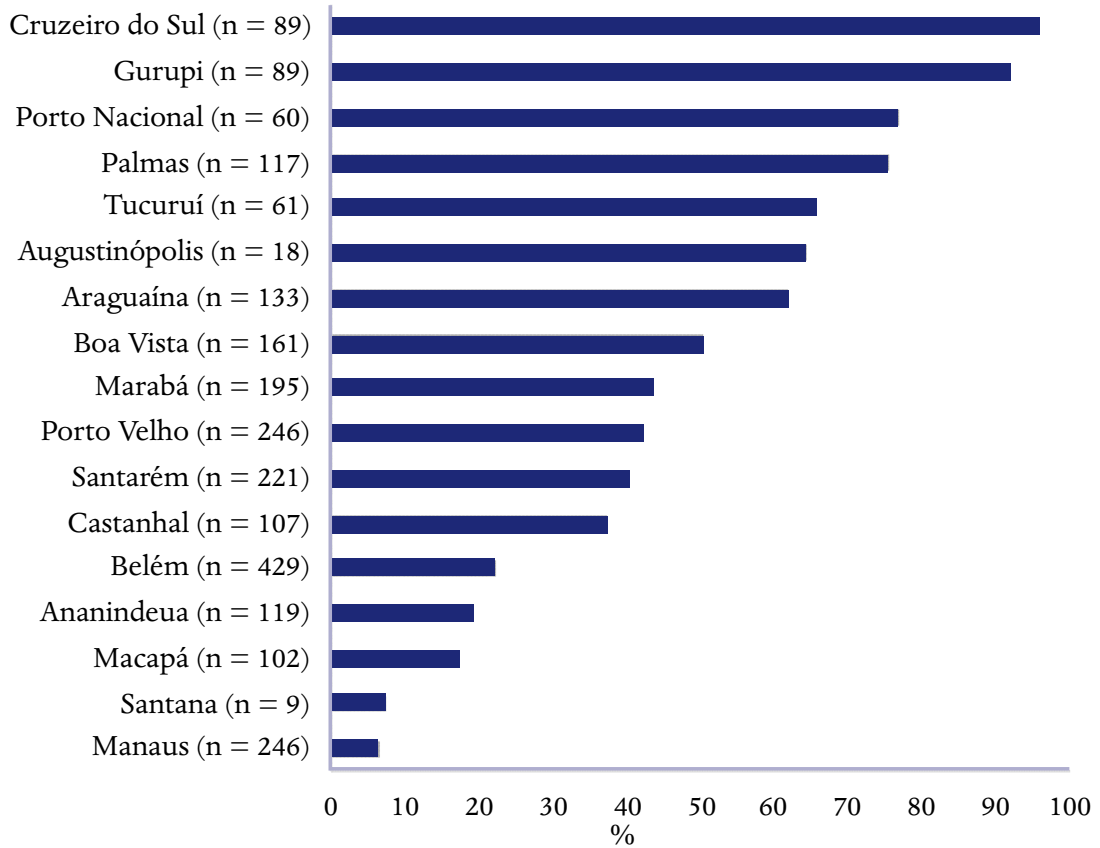

Figure 2. Percentage of priority GC investigated by municipality of residence. North Region, 2017. $\mathrm{n}$ : absolute number of deaths by priority GC investigated.

Source: Mortality Information System. 
Regarding the priority GC, $25.9 \%$ ( $n=2,344$ ) of these codes were investigated and the proportion of investigation codes ranged from $6.8 \%(n=188)$ in Manaus $(A M)$ to $95.7 \%$ $(\mathrm{n}=89)$ in Cruzeiro do Sul (AC). After the investigation, the original underlying cause was changed in $79.1 \%(\mathrm{n}=1,854)$ of the priority GC, and the proportion of change by municipality of residence is shown in Figure 3. In Manaus (AM), there was a change in $34.9 \%$ of the causes of death, while in Cruzeiro do Sul (AC) and Tucuruí (PA) 100\% of the investigated deaths changed the underlying cause of death.

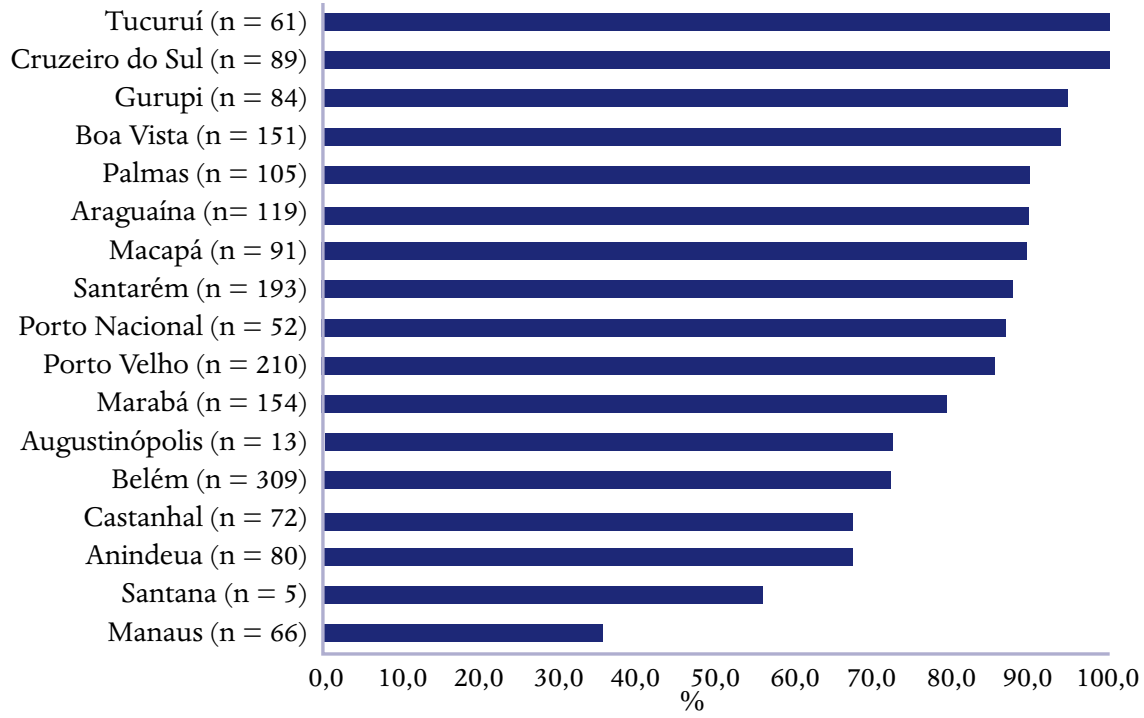

Figure 3. Percentage of priority GC investigated that changed the underlying cause of death by municipality of residence, North Region, 2017.

$\mathrm{n}$ : absolute number of investigated priority GC deaths that changed the underlying cause.

Source: Mortality Information System.

After the investigation, the total number of deaths due to priority GC decreased by $18.4 \%$. All GC groups had a reduction in the number of cases. The largest variation $(-55.9 \%)$ occurred in the group of external causes with undetermined intent and US accidents (Y10Y34, X59), and the smallest variation $(-7.9 \%)$ in the respiratory failure and other respiratory disorders group (J96, J98). The variations are detailed in Table 2.

Table 2. Number of priority garbage codes before and after investigation and proportional variation of the underlying cause of death after investigation. North Region, 2017.

\begin{tabular}{l|c|c|c}
\hline Priority garbage code groups & Before & After & Variation (\%) \\
\hline Ill-defined Causes & 2,777 & 2,412 & -13.1 \\
\hline Stroke unspecified as hemorrhagic or ischemic & 1,313 & 1,083 & -17.5 \\
\hline
\end{tabular}


Table 1. Continuation.

\begin{tabular}{l|c|c|c}
\hline Priority garbage code groups & Before & After & Variation (\%) \\
\hline Septicemia & 529 & 397 & -24.9 \\
\hline Unspecified heart failure and heart disease & 661 & 535 & -19.1 \\
\hline Essential hypertension & 445 & 383 & -13.9 \\
\hline Unspecified neoplasm & 309 & 248 & -19.7 \\
\hline Pulmonary embolism & 62 & 54 & -12.9 \\
\hline Pneumonia & 2,101 & 1,720 & -18.1 \\
\hline Respiratory failure and other respiratory disorders & 165 & 152 & -7.9 \\
\hline Renal failure & 260 & 183 & -29.6 \\
\hline $\begin{array}{l}\text { External causes of undetermined intent and US } \\
\text { accidents }\end{array}$ & 170 & 75 & -55.9 \\
\hline Unspecified traffic accidents and US homicides & 259 & 142 & -45.2 \\
\hline Total & 9,051 & 7,384 & -18.4 \\
\hline
\end{tabular}

Source: Mortality Information System.

\section{DISCUSSION}

This study is very relevant to the Northern population, as it improves the filing of death certificates, providing evidence based on the epidemiological evidences of the region with a correct filling of these DC to support public health policies 5 .

Such importance was evidenced in this study, since approximately $1 / 3$ of all deaths occurred in the region was considered as GC. It is noteworthy that the percentage of investigation varied greatly among the municipalities participating in the research project, which may be justified by the difference in the number of deaths among the municipalities.

This investigation demonstrated that the municipalities with smaller population and single hospital participating in the project were able to achieve higher goals in it. On the other hand, Manaus (AM), which concentrated about $1 / 3$ of deaths per total GC, investigated less than $10 \%$, the lowest proportion among the municipalities included in the project. This can be justified because of its larger population, as well as its large territorial extension and difficult access to rural areas, which are limiting factors. It was also one of the last cities to participate in the project.

The percentage of priority GC deaths found in this study was high. However, it is below the national average $(83.1 \%)$ and there was no noticeable variation between municipalities. It was observed that most of the priority GC deaths changed the underlying cause after the investigation among the analyzed municipalities, thus clearing the underlying 
cause of death. However, the percentage of change between cities was discrepant. These data highlight the importance of continuing the GC investigation aiming at actions that may change this scenario ${ }^{13}$.

The importance of broadening the definition of ill-defined or unspecific codes beyond ill-defined causes was evident in the study by Ishitani et al. ${ }^{6}$. This study analyzed the GC of all capitals of the country and observed that the Northern region has been presenting a reduction of deaths due to ill-defined causes (chapter XVIII of ICD10). However, other GC stood out as important causes of death, showing that only the analysis of ill-defined causes percentage is not enough to assess the quality of information on causes of death ${ }^{14}$.

Kanso et al. $^{15}$, using the definition of GC from the GBD 2000 study, found a higher proportion of unspecific causes than ill-defined causes for the older population in Brazil. Even in countries with a good quality cause-of-death registration system, defining the underlying cause remains a challenge for a number of reasons regarding the process of filing and coding the DC, following international norms and rules 5 .

In Brazil, from 2007 to 2016, there were more than 11 million deaths, of which just over 4 million were notified as GC, representing a percentage of $34 \%$ in relation to the total number of deaths ${ }^{16}$. This high proportion of GC raised the $\mathrm{MoH}$ to seek support from partner institutions to develop a range of initiatives aimed at reducing the proportion of deaths from underlying causes reported in MIS. Investigations of deaths with cause of death classified as GC are among the initiatives developed. This initiative also aims to identify the factors resulting in the maintenance of high proportions of GC and enabled the elaboration of normative and informative material about this issue. Currently, 60 cities in the five regions of the country are participating in the initiative, and it is expected that the results obtained may support the $\mathrm{MoH}$ in expanding and strengthening actions that promote the improvement of the information quality on causes of death in Brazil ${ }^{8}$.

In the analysis of the percentage change of priority GC after the investigation, it was observed that all cause groups had a reduction in the number of deaths from GC and, in general, $18.4 \%$ of these codes were reclassified after the investigation. More than half of the group of undetermined intentional causes and unspecified accidents and nearly half of unspecified traffic accidents and homicides changed the underlying cause after the investigation. For this group of causes, the DC is compulsorily issued by the Institute of Forensic Medicine (IFM), and its database query have contributed to the identification of the underlying cause. In addition, the inclusion of information from other sources, such as police reports and newspapers ${ }^{17}$, is another possibility in the investigation process. Based on these investigations of external causes, there is a need to encourage coroners to improve the filling of DC in all causes of death fields.

Another relevant result refers to deaths from pneumonia $(\mathrm{J} 15.9, \mathrm{~J} 18)$, which were higher before and after the investigation, but with a reduction of $18 \%$. As pointed out by Ishitani and collaborators, there is an additional difficulty in the case of this GC due to the absence 
of microbiological tests in health services, especially because the high cost of these tests6. Further analysis of these deaths is recommended, as immunization is already in place for some age groups, such as children and older people, and therefore pneumonia may not really be the underlying cause of death.

Some GC remain as undetermined intent after investigation by health services, even occurring in hospitals where it is expected easier diagnosis. In the hospitals studied, even after the investigation, less than $80 \%$ of priority GC changed the underlying cause to a more specific one. The existence of GC in hospitals may be due to failures in the filling of DC by doctors. Mendonça and collaborators ${ }^{18}$ have highlighted as the main problems related to the filling of the DC: medical unfamiliarity about the importance of filling correctly all fields of the form and about the detailing and the adequacy of the pathological events chain regarding possible causes of death; the limited use of instructional materials provided to physicians by the responsible health agencies and institutions.

Thus, in the operationalization of MIS aiming at the production of quality information, it is necessary to face problems such as the lack of human resources training, supervision and control, and the high turnover of technicians for information management at the municipal level ${ }^{19}$. Actions for information qualification should include, more constantly and permanently, training aimed at physicians and coders for the proper information recording. Undergraduate Medicine courses should also include, in their curriculum, discipline on the quality of information on death, in order to make students aware of the importance of correctly filling of DC.

The process of improvement through guidance and explanation directed to health professionals by the municipal health department usually results in reduced GC. There are also issues related to diagnostic difficulties. The etiological diagnosis of pneumonia, for example, represents a challenge, since the request for microbiological tests is not routinely made in health services. For similar difficulty, septicemia is often declared unspecified ${ }^{6}$. Essential hypertension is regarded in the GBD study as a risk factor, being classified as GC because of its low utility when declared as the underlying cause of death. It may be related to different disease categories, such as ischemic heart disease, ischemic cerebrovascular disease, cerebrovascular hemorrhagic, chronic kidney disease, among others ${ }^{20}$. Thus, when the physician declares only essential hypertension in DC, it is selected as the underlying cause and information on associated diseases is lost $^{6}$.

The fact that the investigation was restricted to hospitals in the municipalities analyzed has to be considered, given that there is still a significant number of deaths due to GC occurring at home. In this case, the DC can be completed by the doctor or institution that provided care to the patient, if it can relate the death to previous clinical picture or the use of verbal autopsy form to collect information to help identify the cause of death ${ }^{4}$.

From the analysis of the presented data, it was observed that the investigation and change of the total and priority GC was relevant, even with few available resources and performed in hospital. The study allowed to obtain important information about the quality of filling 
the DC in the studied hospitals, besides contributing to the improvement of the information quality in mortality, through the upgrade of the MIS, ensuring a more reliable information system.

\section{CONCLUSION}

This study indicate the need for greater efforts in the investigation of deaths from GC, as well as expanding the number of services that perform the investigation, aiming to elucidate the underlying cause of death and the MIS improvement. The correct filling of DC by physicians, greater access to medical care and diagnosis are key to reducing GC and, consequently, insuring good quality information on the causes of death. Raising awareness and training of physicians about their role in producing information on cause of death is a priority in the continuing education of these professionals.

\section{REFERENCES}

1. França EB, Passos VMA, Malta DC, Duncan BB, Ribeiro ALP, Guimarães MDC, et al. Cause-specific mortality for 249 causes in Brazil and states during 19902015: a systematic analysis for the global burden of disease study 2015. Popul Health Metr. 2017;15(1):39. https: / / doi.org/10.1186/s12963-017-0156-y

2. Brasil. Ministério da Saúde. Fundação Nacional da Saúde. Manual de procedimentos do Sistema de Informações sobre Mortalidade [Internet]. Brasília, DF; 2001 [cited 2019 Aug 27]. Available from: http:/ / bvsms.saude.gov.br/ bvs/publicacoes/sis_mortalidade.pdf

3. Brasil. Ministério da Saúde. Secretaria de Vigilância em Saúde. Manual para investigação do óbito com causa mal definida [Internet]. Brasília, DF; 2009 [cited 2019 Aug 27]. Available from: http://svs. aids.gov.br/download/manuais/manual_obito_ mal_definida.pdf

4. França EB, Teixeira RA, Ishitani LH, Duncan BB, Cortez-Escalante JJ, Morais Neto OL, et al. Causas mal definidas de óbito no Brasil: método de redistribuição baseado na investigação do óbito. Rev Saúde Pública. 2014;48(4):671-81. https:// doi.org/ 10.1590/S0034-8910.2014048005146

5. Naghavi M, Makela S, Foreman K, O’Brien J, Pourmalek F, Lozano R. Algorithms for enhancing public health utility of national causes-of-death data. Popul Health Metr. 2010;8(1):9. https:/ / doi.org/doi.org/ 10.1186/1478-7954-8-9

6. Ishitani LH, Teixeira RA, Abreu DMX, Paixão LMMM, França EB. Qualidade da informação das estatísticas de mortalidade: códigos garbage declarados como causas de morte em Belo Horizonte, 20112013. Rev Bras Epidemiol. 2017;20(Suppl 1):34-45. https: / / doi.org/10.1590/1980-5497201700050004

7. Brasil. Ministério da Saúde. Secretaria de Vigilância em Saúde. Encontro Sobre a Melhoria da Qualidade da Informação sobre Causas de Morte no Brasil: relatório [Internet]. Brasília, DF; 2017 [cited 2019 Aug 27]. p. 87-133. Available from: https: / / issuu.com/paulafreitas55/docs / relat_rio_pe_azul-ilovepdf-compres

8. Lima RB. Avaliação do protocolo utilizado para investigação de óbitos por causa garbage nas sessenta cidades. In: Encontro sobre a melhoria da qualidade da informação sobre causas de morte no Brasil; 2017 out. 2-6; Pernambuco (Br). Brasília, DF: Ministério da Saúde; 2017 [cited 2019 Sept 2]. Available from: http://svs.aids.gov.br/dantps/centrais-de-conteudos/ eventos/2017/pernambuco/

9. Mathers CD, Fat DM, Inoue M, Rao C, Lopez AD. Counting the dead and what they died from: an assessment of the global status of cause of death data. Bull World Health Organ [Internet]. 2005 [cited 2019 Aug 27];83(3):171-7. Available from: https: / / www.ncbi.nlm.nih.gov/pmc/articles / PMC2624200/pdf/15798840.pdf

10. Cunha CC, Teixeira R, França E. Avaliação da investigação de óbitos por causas mal definidas no Brasil em 2010. Epidemiol Serv Saúde. 2017;26(1):19-30. https://doi.org/10.5123/s1679-49742017000100003 
11. Instituto Brasileiro de Geografia e Estatística. Divisão territorial brasileira [Internet]. Rio de Janeiro; 2011 [cited 2019 Aug 28]. Available from: https://ww2. ibge.gov.br/home/geociencias/cartografia/default_ dtb_int.shtm

12. Instituto Brasileiro de Geografia e Estatística. Estimativas populacionais para os municípios e para as unidades da Federação brasileiros em 01.07.2017 [Internet]. Rio de Janeiro; 2017 [cited 2019 Aug]. Available from: https: / ww2.ibge.gov.br/ home/estatistica/populacao/estimativa2017/ estimativa_dou.shtm

13. GBD 2015 Mortality and Causes of Death Collaborators. Global, regional, and national life expectancy, all-cause mortality, and cause-specific mortality for 249 causes of death, 1980-2015: a systematic analysis for the Global Burden of Disease Study 2015. Lancet. 2016;388:1459-544. doi. org/10.1016/S0140-6736(16)31012-1

14. Costa MR, Marcopito LF. Mortalidade por causas mal definidas, Brasil, 1979-2002, e um modelo preditivo para idade. Cad Saúde Pública [Internet]. 2008 [cited 2019 Aug 28];24(5):1001-12. Available from: https: / / www.scielosp.org/article/csp/ 2008. v24n5/1001-1012/

15. Kanso S, Romero DE, Leite IC, Moraes EN. Diferenciais geográficos, socioeconômicos e demográficos da qualidade da informação da causa básica de morte dos idosos no Brasil. Cad Saúde Pública. 2011;27(7):1323-39. https:/ / doi.org/10.1590/ S0102-311X2011000700008

16. Barbosa RS, Maciel MCC. Códigos garbage como causa básica de óbito na IV GERES/ PE, 2007-2016 [trabalho de conclusão de residência]. Recife: Escola de Governo em Saúde Pública de Pernambuco; 20162018 [cited2019 Sept 2]. Available from: http:// ead. saude.pe.gov.br $/ \mathrm{mod} /$ folder $/$ view.php?id $=10665$

17. Ladeira RM, Guimarães MDC. Análise da concordância da codificação de causa básica de óbito por acidentes de trânsito. Rev Saúde Pública. 1998;32(2):133-7. https: / / doi.org/10.1590/S0034-89101998000200005

18. Mendonça FM, DrumondE, Cardoso AMP. Problemas no preenchimento da Declaração de Óbito: estudo exploratório. Rev Bras Estud Popul. 2010;27(2):285-95. https: / / doi.org/10.1590/S0102-30982010000200004

19. Frias PG, Pereira PMH, Andrade CLT, Szwarcwald CL. Sistema de Informações sobre Mortalidade: estudo de caso em municípios com precariedade dos dados. Cad Saúde Pública. 2008;24(10):2257-66. https: / doi.org/10.1590/S0102-311X2008001000007

20. Truelsen T, Krarup LH, Iversen HK, Mensah GA, Feigin VL, Sposato LA, Naghavi M. Causes of Death Data in the Global Burden of Disease Estimates for Ischemic and Hemorrhagic Stroke. Neuroepidemiology. 2015;45(3):152-60. doi.org/ $10.1159 / 000441084$

Received: 06/10/2019

Final version presented on: 08/01/2019

Accepted: 08/14/2019

Acknowledgments: To the national coordination of the project Dados para a Saúde (Data for Health), Professor. França EB from Universidade Federal de Minas Gerais, and to the state coordinators: Maia RLO, Secretariat of State for Health (SES) (AC); Cabrinha AA, SES (AM); Alberto DS, SES (AP); Monteiro JRAR, SES (PA); Alves MMM, SES (RO); Vieira Filho J, SES (RR); and Silva CV, SES (TO). To A Wagner S. Jesus, technical consultant of MS. To Dra.Marinho MF, SVS / MS.

Authors' contribution: Benedetti MSG, Saraty SB and Martins AG worked in the study conception, analysis and interpretation of data, in the article's writing and critical review. Daisy Abreu DMX and Miranda MJ contributed to the data analysis and critical review of the text. All authors reviewed and approved the final version of the article. 